\title{
EXHAUSTIVE STUDY OF THE PV MODULE IMPLEMENTED IN THE REGION OF ANNABA- ALGERIA
}

\author{
A. Dekhane ${ }^{1 *}$, B. Lamri², N. Benamira ${ }^{2}$ \\ ${ }^{1}$ The Higher School of Industrial Technologies - Annaba, ALGERIA \\ *e-mail: a.dekhane@esti-annaba.dz \\ ${ }^{2}$ Badji Mokhtar - Annaba University, ALGERIA \\ e-mail: billel_la@hotmail.fr; nadir.benamira@gmail.com
}

Algeria, like any other country, has drawn up its roadmap for the use and promotion of renewable energy sources. Motivated by its commitment to the international community in the fight against global warming and its possession of one of the largest solar fields in the world, a series of laws and institutions have consolidated this ambitious schedule. As known, both the climate and the geological area of Algeria take place among the foremost favoured countries in the field of solar energy. The present paper aims at proposing a simple model of photovoltaic module.

The authors used Matlab/Simulink software to predict the current-voltage and powervoltage characteristics according to the influence of several factors, such as solar irradiance, cell temperature and series resistance, on the efficiency of photovoltaic module. The proposed experimental investigation can easily predict the curves (current-voltage and power-voltage) of a PV module, where both of simulation and practical results are identical. A single-crystalline photovoltaic module was introduced close to Badji-Mokhtar Annaba University, Annaba (Algeria) to show the impact of climatic conditions in this coastal region and partial shading on characteristics.

Keywords: Algeria, photovoltaic module, series resistance effects, shading effects, simulation model, solar energy.

\section{INTRODUCTION}

Nowadays, the development of renewable energy sources of all kinds, such as solar energy, wind energy, biomass energy etc., to produce electric energy has become more necessary than ever. The reason for this orientation is significant depletion of fossil 
fuel stocks caused by increasing demand of manufacturers in developed countries. Furthermore, the emergence of natural disasters, due to global warming effect (the increased levels of carbon dioxide, chlorofluorocarbons, and other pollutants in the atmosphere), will affect the lives of future generations [1], [2]. All these factors have led scientists and researchers to study how to make good use of these renewable and environmentally friendly energy sources so that they can become alternative energy in the future.

Solar energy is one of the most important renewable energy sources due to its availability throughout the year and its presence almost everywhere. Solar energy represents a significant potential in Algeria because of its strategic geographic location.

According to the Centre for the Development of Renewable Energies in Algeria, average solar energy is estimated at 2,650 hours of sunshine per year in the north, and 3,000 hours in the highlands, 3,500 hours in the south of the desert. This allows Algeria to produce around 168.971 TWh of electricity per year, twice the capacity of Egypt and more than 100 times of Spain, which gives Algeria the preference to exploit this green energy [3].

There are two technologies for harnessing solar energy, the first being solar photovoltaic technology, which directly converts the sunlight into electricity through the use of semiconductor materials, such as silicon, that exhibit the photovoltaic effect [4]. The second is the solar thermal technology [5], which directly converts solar radiation into thermal energy used to heat domestic water and generate electricity indirectly as in Concentrating Solar Power [4], [6].

A PV module is a set of PV cells connected together in series or series / parallel in order to increase the power delivered by the PV cell. To increase the power produced up to a few MW, it is sufficient to connect the PV modules to each other in series / parallel and form what is called a PV field.

A photovoltaic system is subject to several factors that affect its performance, such as sunlight, temperature, shading [7]-[9], degradation [10], [11], [7], dust and dirt etc.

Studying the characteristics of PV modules is the most practical method for evaluating the performance of PV systems. Several researchers work in this field and have developed simulation models that simulate a PV module-PV field and give equations to calculate the parameters of these models [12]-[15]. However, an experimental study is needed to confirm the effectiveness of the simulation model especially for the east of Algeria like Annaba's region, which was never taken into consideration for such an exploratory study.

An experimental study has been carried out using a PV module Solo Line 80 model, which presented the effects of climate conditions in 'SIDI AMAR', Annaba city (Algeria), on its characteristics (I-V and $\mathrm{P}-\mathrm{V})$.

We propose a simple model of this PV module, using Matlab/Simulink Software, to calculate the PV module parameters of single-diode model and to predict its current-voltage and power-voltage curves according to the influence of several factors. We used in this model the input parameters provided by manufacturer's datasheet under Standard Test Conditions (STC) $(\mathrm{G}=1000$ $\mathrm{W} / \mathrm{m}^{2}$ and $\mathrm{T}=25^{\circ} \mathrm{C}$ ) such as Isc, Voc, ki, Ns, Imp, Vmp, kv. The curves of currentvoltage and power-voltage of the PV module obtained experimentally illustrate the impact of partial shading on the PV module performance. 


\section{A. Photovoltaic Module Modelling}

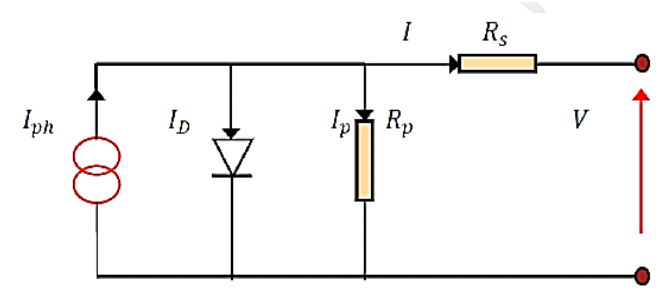

Fig. 1. Equivalent electrical circuit of photovoltaic module.

The electrical circuit of photovoltaic module based on the single-diode model $[12,15]$ is shown in Fig. 1, and described in Eq. (1).

$I=I_{p h}-I_{0} \cdot\left[\exp \left(\frac{V+I \cdot R s}{a \cdot V t}\right)-1\right]-\left(\frac{V+I \cdot R s}{R p}\right)$,

where

$I \quad$ is the output current of PV module (A);

$I_{p h}$ is the photovoltaic current (A);

$I_{0}$ is the saturation current of diode;

$V$ is the output voltage of PV module;

$V t$ is the thermal voltage;

$a$ is the diode ideality factor;

$R_{S}$ and $R_{p}$ are series resistance and shunt resistance, respectively.

The photovoltaic current mainly depends on the radiation intensity and cell operating temperature as follows [13], [16]:

$I_{p h}=\left[I_{s c}+k_{i} *\left(T-T_{r e f}\right)\right] * \frac{s}{S_{r e f}}$,

where

$I_{s c}$ is the short-circuit current $(A)$;

$k_{i}$ is the short-circuit current coefficient $\left(A /{ }^{\circ} \mathrm{C}\right)$;

$T$ is the temperature of the $\mathrm{p}-\mathrm{n}$ junction solar cell in $K$;

$S$ is the solar radiation $\left(\mathrm{W} / \mathrm{m}^{2}\right)$;

$S_{\text {ref }}$ is solar radiation at standard test conditions STC $\left(25^{\circ} \mathrm{C}, 1000 \mathrm{~W} / \mathrm{m}^{2}\right)$;
$T_{r e f}$ is the temperature at standard test conditions $\operatorname{STC}\left(25^{\circ} \mathrm{C}, 1000 \mathrm{~W} / \mathrm{m}^{2}\right)$.

The saturation current of PV module is expressed in the following equation [7]:

$I_{0}=I_{r 0} *\left[\left(\frac{T}{T_{r e f}}\right)^{3} * \exp \left(\frac{q * E_{g}}{a * k} *\left(\frac{1}{T_{r e f}}-\frac{1}{T}\right)\right)\right]$,

where

$I_{r 0}$ is the reverse saturation current $(A)$;

$k$ is the Boltzmann constant $(1.38 * 10-23$ $J / K)$;

$q$ is the electron charge $\left(1.6 * 10-19{ }^{\circ} \mathrm{C}\right)$;

$E_{g}=1.12$, is the Silicon Gap Energy $(\mathrm{eV})$.

Temperature is one of the metrological parameters that affects the performance and degradation of PV modules (especially those installed in desert areas) [9], [10]. Equation (4) describes the mathematical calculation of the temperature of PV cells under the effect of ambient temperature:

$T_{m}=T_{a m b}+\left(\frac{T_{N o c T}-T_{r e f}}{S_{r e f}}\right) * S$,

where $T_{a m b}$ is the ambient temperature, and TNOCT is the nominal operating cell temperature (NOCT) for operating at open circuit with the following conditions: ambient temperature of $20^{\circ} \mathrm{C}$, irradiance $\mathrm{S}=0,8 \mathrm{~kW} /$ $m^{2}$, air mass (AM 1.5) and wind speed less than $1 \mathrm{~m} / \mathrm{s}$ [13]. 


\section{EXPERIMENTAL SETUP}

The experimental results of PV module characteristics are obtained through the experimental setup as shown in Fig. 2. The PV module is mounted at Sidi Amar, in Annaba (latitude: $36^{\circ} 49^{\prime} 3.58$ "North, longitude: $7^{\circ} 43^{\prime} 4.55^{\prime}$ ' East and altitude 34 $\mathrm{m})$. The tools and measuring devices are a PV module Luxor Solo Line 80, solarimeter Voltcrraft PL-110SM, Fluke 59 MAX infrared thermometer, multimeters, rheostat, and connection wires.

Furthermore, the proposed simulation model of PV module is presented in Fig. 3, where the solar irradiance, module temperature, open-circuit voltage at STC, short- circuit current at STC, and the number of cells per module are the inputs of model, while its outputs are the current and power.

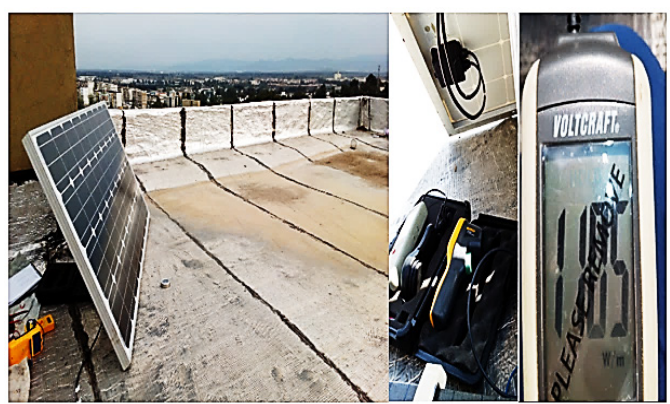

Fig. 2. Experimental setup and measurement devices.

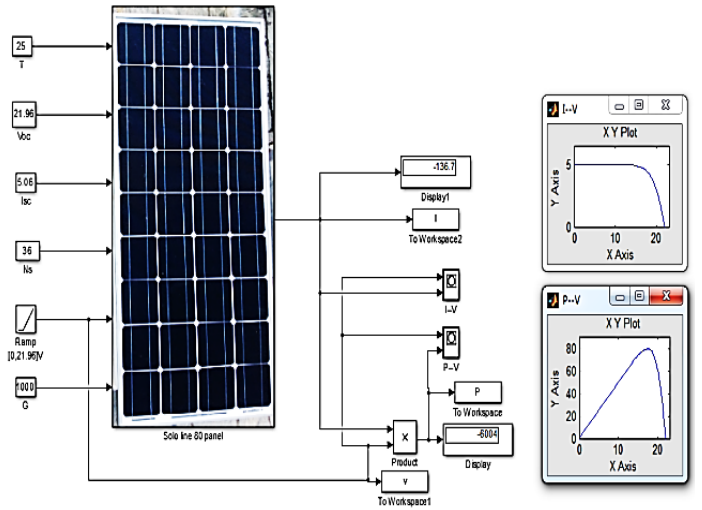

Fig. 3. Simulation model of a PV module.

Table 1 presents specific electrical parameters of PV module used in this study.

Table 1. Specification of the PV Module (Luxor Solo Line 80)

\begin{tabular}{|c|c|}
\hline Parameters & Value \\
\hline Maximum power (Pmp) & $80 \mathrm{~W} \mathrm{(+/-3 \% )}$ \\
\hline Maximum power voltage (Vmp) & $17.86 \mathrm{~V}$ \\
\hline Maximum power current (Imp) & $4.50 \mathrm{~A}$ \\
\hline Open circuit voltage (Voc) & $21.96 \mathrm{~V}$ \\
\hline Short-circuit current (Isc) & $5.06 \mathrm{~A}$ \\
\hline Max system voltage & $1000 \mathrm{~V}$ \\
\hline Number of cells per module (Ns) & 36 \\
\hline
\end{tabular}




\section{RESULTS AND DISCUSSION}

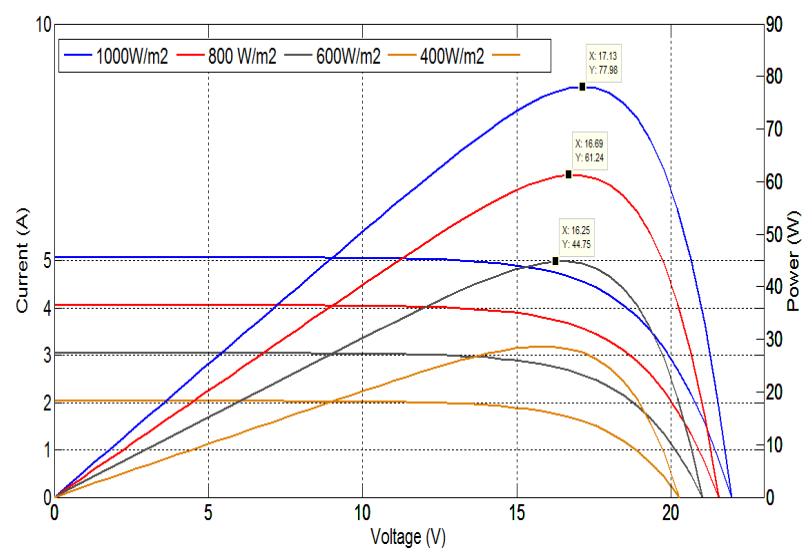

Fig. 4. (I-V\& P-V) curves of PV module at different solar illumination values and constant temperature.

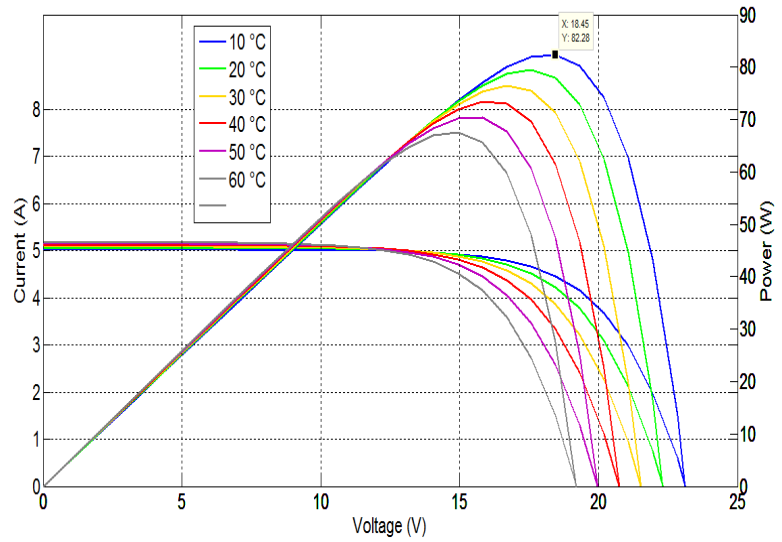

Fig. 5. (I-V\& P-V) curves of PV module at different temperature values and constant solar illumination.

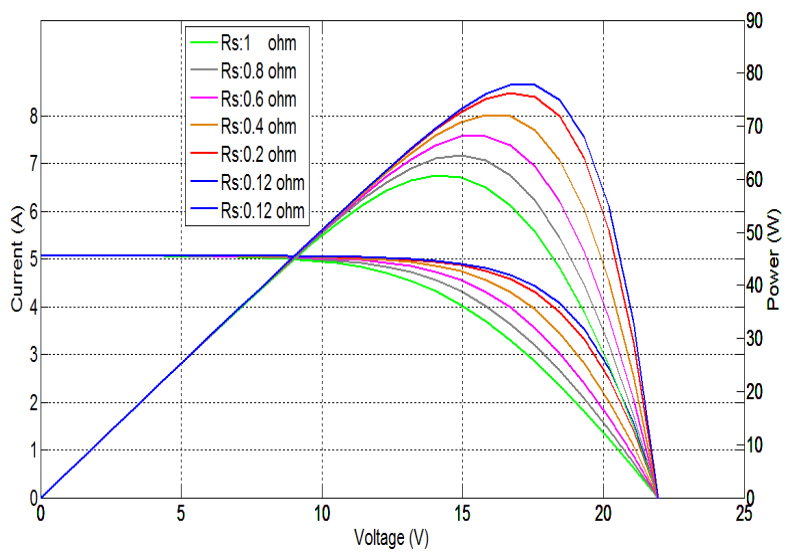

Fig. 6. Characteristic curves of PV module for different Rs values. 
Figure 4 illustrates the current and power curves of PV module under different solar irradiance values $\left(400 \mathrm{~W} / \mathrm{m}^{2}\right.$ to 1000 $\mathrm{W} / \mathrm{m}^{2}$ ) obtained by simulation.

We observe from Fig. 4 that the increase in the solar irradiance value is accompanied by an increase in a short-circuit current value of PV module, which also leads to an increase in the maximum power value, and the opposite is true. While the increase in the solar irradiance value leads to a smaller increase in the open-circuit voltage value.

MATLAB simulation result of the purposed PV module in Fig. 5 shows I-V and $\mathrm{P}-\mathrm{V}$ characteristics curves of PV module obtained under different values of PV module temperature $\left(10{ }^{\circ} \mathrm{C}\right.$ to $\left.60{ }^{\circ} \mathrm{C}\right)$, and with constant solar irradiance value $\left(1 \mathrm{KW} / \mathrm{m}^{2}\right)$.
We notice from both curves in Fig. 5 that the increase in the module temperature value leads to the decrease in the opencircuit voltage value, which results in a decrease in the maximum power point of PV module, while the short-circuit current value stays almost constant.

Figure 6 explains the effect of series resistance Rs on the I-V and P-V curves of PV module.

We notice that the increase in the series resistance values due to bad contacts, cell defect or other problems (degradation) [11] leads to a change in the form of curves from knee-shape to a straight-shape curve (Fig. 6) because of the decrease in the terminal voltage values of PV module. Thus, it leads to the decrease in the maximum power point.

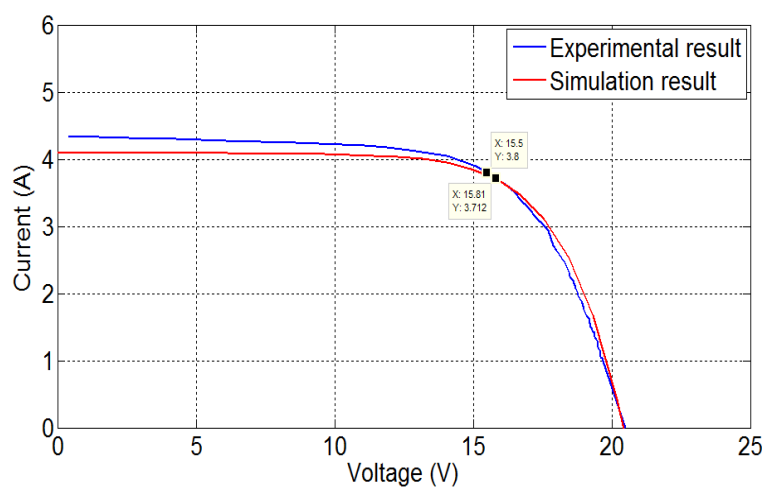

(a)

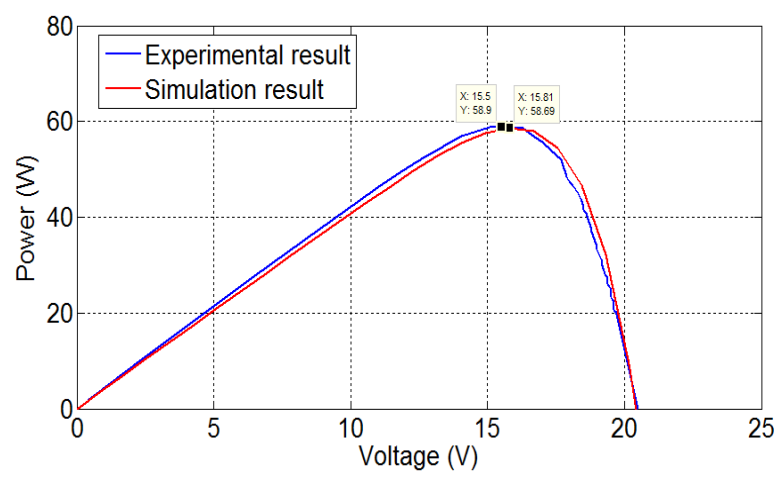

(b)

Fig. 7. Experimental and simulation, (a) I-V and (b) P-V characteristics of PV module. 
Figure $7(\mathrm{a}, \mathrm{b})$ illustrates the currentvoltage and power-voltage curves, respectively, of PV module taken under outside conditions (blue curves), while the simulation results are shown in the red curves.

We notice that the maximum power produced by the PV module was about $58.9 \mathrm{~W}$ on 14 April 2017 at $10.22 \mathrm{H}\left(\mathrm{S}=820 \mathrm{~W} / \mathrm{m}^{2}\right.$ and $\mathrm{T}=44{ }^{\circ} \mathrm{C}$ ) (see Fig. 10), corresponding to the maximum current and voltage $(3.8 \mathrm{~A}$, $15.5 \mathrm{~V})$. Moreover, the results of simula- tion model and experimental measurements are identical, as shown by the red and blue curves in Fig. 7.

Figures 8 and 9 show the influence of shading on the characteristics of PV module. Figure 8 demonstrates the current-voltage and power-voltage curves of shading of PV module (PV half-cell), while Fig. 9 illustrates the influence of shading of a PV cell on the performance of PV module.

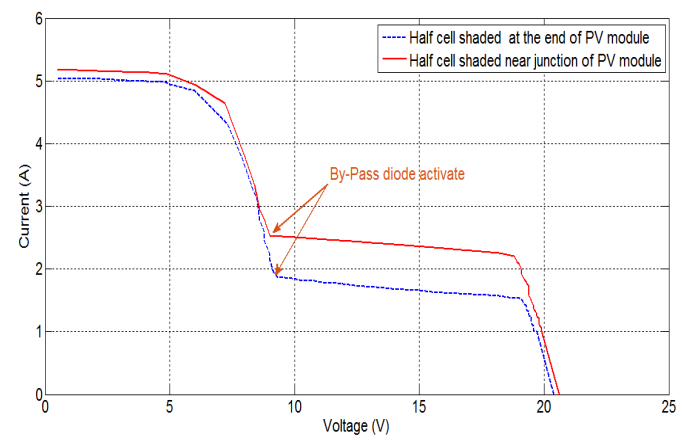

(a)

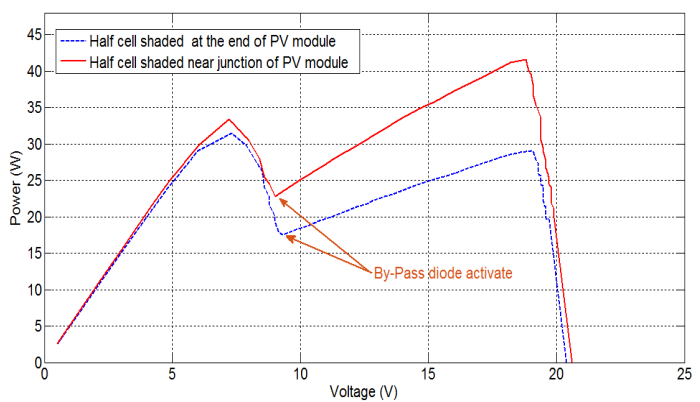

(b)

Fig. 8. Experimental (a) I-V and (b) P-V characteristics of PV module shaded half-cell at end, near junction.

In Fig. 8, we note that the shape of the current curve becomes a shape of two knees (Fig. 8 (a)) and two peaks in the power curve (Fig. 8 (b)) due to the inadequacy of the sunlight that reaches the shaded PV cell of the PV module (half PV cell). This leads to a reduction in the current and power of the PV module.
In Fig. 9, one observes an important division in the curve of the current and power due to the operation of the by-pass diode, which occupies the series of cells connected with the shaded PV cell, in order to protect them from hot-spot phenomenon. This leads to a significant decrease in power and PV module current. 
We conclude from the experimental results (Figs. 8 and 9) that shading has a significant impact on the performance of the PV module.

Figure 10 presents the variation of solar illumination and the cell temperature values taken in the clear day, on 14 April 2017 in Sidi Amar, ANNABA. We can see that irradiance reaches the maximum value of 960
$\mathrm{W} / \mathrm{m}^{2}$ at 11:44 and decreases until sunset. Furthermore, the value of solar irradiance in this region can reach around $1100 \mathrm{~W} / \mathrm{m}^{2}$ in the middle of the day in April, indicated by solarimeter instrument (see Fig. 2). These values of solar irradiance and cell temperature according to daylight hours are shown in Fig. 10.

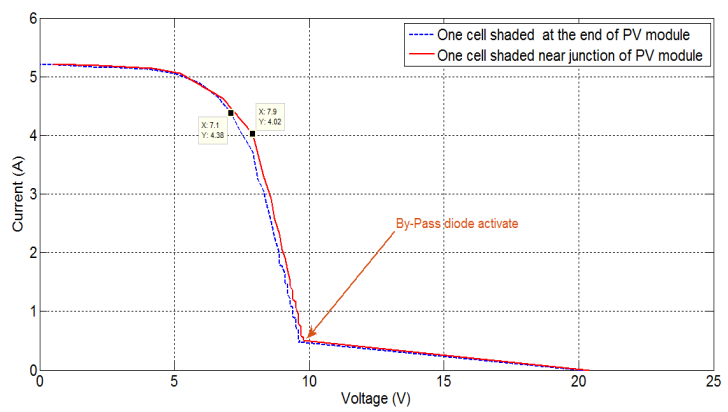

(a)

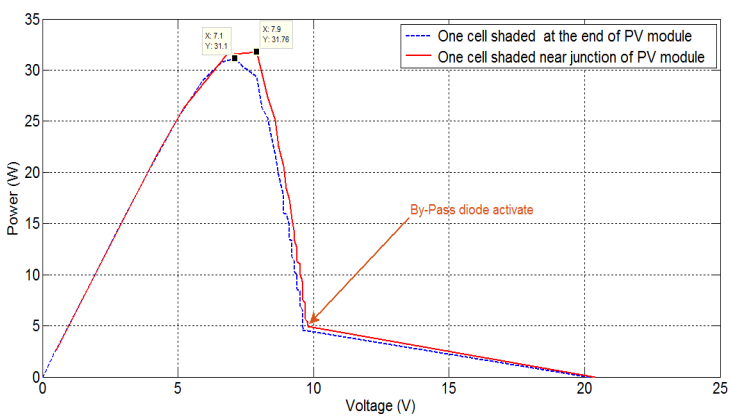

(b)

Fig. 9. Experimental (a) I-V and (b) P-V characteristics of PV module shaded one cell at end, near junction.

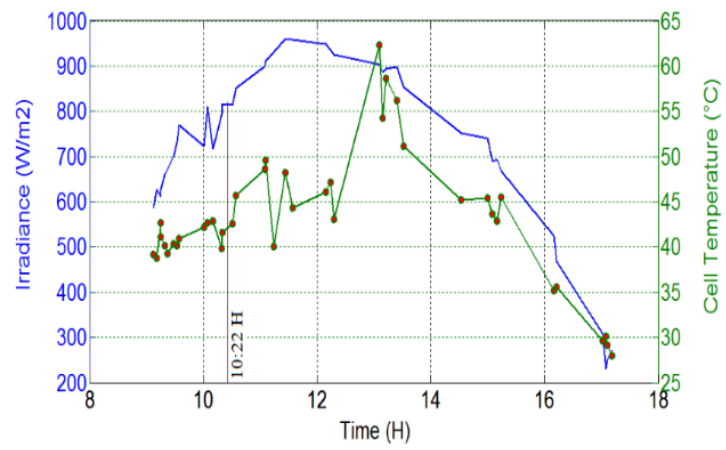

Fig. 10. Solar irradiance and cell temperature taken on a clear day. 
From the research carried out, an experimental study has been presented. Its aim has been to show the influence of the climate of Sidi Amar, Annaba (Algeria), on the characteristics $(\mathrm{I}-\mathrm{V})$ and $(\mathrm{P}-\mathrm{V})$ of the PV module, Luxor Solo Line 80.

A simple simulation model has been presented to determine the parameters of any PV module, as well as to forecast its characteristics. From the outcome of our investigation, it is possible to conclude that the comparison seems to demonstrate that the experimental results and the simulation results are almost identical, which proves the credibility of this model.

Summing up the results, it can be concluded that the proposed strategy and involvement should therefore have wide application, and researchers can rely on this demonstration to explore PV module degradation for these particular regions of
Algeria, which have never been taken into consideration in previous research.

Finally, we encourage the use of this important branch of renewable energy in the Annaba region in several domains: agriculture, autonomous electrical system, pumping with a direct and high socio-economic impact such as employment opportunities, engineering activity development and design, procurement and production capacities to reach an adequate industrial integration capacity. All things being equal, the economic impact of this purpose seems positive.

It could also be used to provide electricity to relatively undeveloped regions that are not connected to the national grid.

Based on the promising results presented in this paper, work on the remaining issues is ongoing and will be presented in future papers.

\section{REFERENCES}

1. Halkos, G.E., \& Tsilika, K.D. (2017). Climate Change Effects and their Interactions: An Analysis Aiming at Policy Implications. Economic Analysis and Policy, 53, 140-146. DOI: 10.1016/j.eap.2017.01. 005.

2. Prăvălie, R. (2018). Major Perturbations in the Earth's Forest Ecosystems. Possible Implications for Global Warming. EarthScience Reviews, 185, 544-571. DOI: 10.1016/J.EARSCIREV.2018.06.010.

3. Jeffres, A., Grimditch, P., Taslima, R., \& Pinson, T. (eds.). (2014). The Report Algeria. Oxford Business Group. Available at https://oxfordbusinessgroup.com/algeria2014

4. Allina, G.P., \& Burns, M.E. (2019). Harnessing the Sun to See Anew. Neuron,
102 (6), 1093-1095. DOI: 10.1016/j. neuron.2019.05.051

5. Hansen, K., \& Mathiesen, B.V. (2018). Comprehensive Assessment of the Role and Potential for Solar Thermal in Future Energy Systems. Solar Energy, 169, 144 152. DOI: 10.1016/j.solener.2018.04.039.

6. Bader, R., \& Lipiński, W. (2017). Solar Thermal Processing. Advances in Concentrating Solar Thermal Research and Technology, 403-459. ISBN 9780081005163.

7. Lamri, B., Abderrezak, A., Razem, H., \& Kahoul, N. (2018). Shading and Diode Fault Effects on PV Array Performances. Transactions on Electrical and Electronic Materials, 19, 75-83. DOI: 10.1007/ s42341-018-0021-0. 
8. Das, P., Mohapatra, A., \& Nayak, B. (2017). Modeling and Characteristic Study of Solar Photovoltaic System under Partial Shading Condition. Materials Today, 4 (14), 1258612591. DOI: 10.1016/j.matpr.2017.10.066.

9. Lupangu, C. \& Bansal, R. C. (2017). A Review of Technical Issues on the Development of Solar Photovoltaic Systems. Renewable and Sustainable Energy Reviews, 73, 950-965. DOI: 10.1016/j.rser.2017.02.003.

10. Bouraiou A., Hamouda M., Chaker A., Mostefaouia, M., Lachtar, S., Sadok M., ... \& Issam, A. (2015). Analysis and Evaluation of the Impact of Climatic Conditions on the Photovoltaic Modules Performance in the Desert Environment. Energy Conversion and Management, 106, 1345-1355. DOI: 10.1016/j.enconman.2015.10.073.

11. Bouraiou, A., Hamouda, M., Chaker, A., Lachtar, S., Neçaibia, A., Boutasseta, N., \& Mostefaoui, M. (2017). Experimental Evaluation of the Performance and Degradation of Single Crystalline Silicon Photovoltaic Modules in the Saharan Environment. Energy, 1-28. DOI: 10.1016/j.energy.2017.05.056.

12. Askarzadeh, A., \& Coelho, L. d. S. (2015). Determination of Photovoltaic Modules Parameters at Different Operating Conditions Using a Novel Bird Mating Optimizer Approach. Energy Conversion and Management, 89, 608-614. DOI: 10.1016/j.enconman.2014.10.025.
13. El Achouby, H., Zaimi, M., Ibral, A., \& Assaid, E.M. (2018). New Analytical Approach for Modelling Effects of Temperature and Irradiance on Physical Parameters of Photovoltaic Solar Module. Energy Conversion and Management, 177, 258-271. DOI: 10.1016/j. enconman.2018.09.054.

14. Polo, J., Martín-Chivelet, N., AlonsoGarcía, M.C., Zitouni, H., AlonsoAbella, M., Sanz-Saiz, C., \& VelaBarrionuevo, N. (2019). Modeling I-V Curves of Photovoltaic Modules at Indoor and Outdoor Conditions by Using the Lambert Function. Energy Conversion and Management, 195, 1004-1011. DOI; 10.1016/j.enconman.2019.05.085.

15. Ma, T., Yang, H., \& Lu, L. (2014). Development of a Model to Simulate the Performance Characteristics of Crystalline Silicon Photovoltaic Modules/Strings/ Arrays. Solar Energy, 100, 31-41. DOI; 10.1016/j.solener.2013.12.003.

16. Belhachat, F., \& Larbes, C. (2015). Modeling, Analysis and Comparison of Solar Photovoltaic Array Configurations under Partial Shading Conditions. Solar Energy, 120, 399-418. DOI: 10.1016/j. solener.2015.07.039. 